\title{
Cucurbits Plants: A Key Emphasis to Its Pharmacological Potential
}

\author{
Bahare Salehi $^{1}\left(\mathbb{D}\right.$, Esra Capanoglu ${ }^{2}\left(\mathbb{D}\right.$, Nabil Adrar $^{3}(\mathbb{D})$, Gizem Catalkaya ${ }^{2}$, \\ Shabnum Shaheen ${ }^{4}\left(\mathbb{D}\right.$, Mehwish Jaffer ${ }^{4}$, Lalit Giri ${ }^{5}{ }^{\mathbb{D}}$, Renu Suyal ${ }^{5}$, Arun K Jugran ${ }^{6}$, \\ Daniela Calina ${ }^{7}$ D , Anca Oana Docea ${ }^{8}$, Senem Kamiloglu 9 ${ }^{\mathbb{D} \text {, Dorota Kregiel }}{ }^{10} \mathbb{D}^{\text {, }}$ \\ Hubert Antolak 10 (D), Ewelina Pawlikowska ${ }^{10}$, Surjit Sen ${ }^{11,12}$, Krishnendu Acharya ${ }^{11}$, \\ Zeliha Selamoglu ${ }^{13}$, Javad Sharifi-Rad ${ }^{14, *(D)}$, Miquel Martorell 15,*(D), Célia F. Rodrigues 16 (D), \\ Farukh Sharopov ${ }^{17}$ (D), Natália Martins ${ }^{18,19, *(1)}$ and Raffaele Capasso ${ }^{20, *}$
}

1 Student Research Committee, School of Medicine, Bam University of Medical Sciences, Bam 44340847, Iran; bahar.salehi007@gmail.com

2 Faculty of Chemical \& Metallurgical Engineering, Food Engineering Department, Istanbul Technical University, 34469 Maslak, Turkey; capanog1@itu.edu.tr (E.C.); catalkaya.gizem@gmail.com (G.C.)

3 Laboratoire de Biotechnologie Végétale et d'Ethnobotanique, Faculté des Sciences de la Nature et de la Vie, Université de Bejaia, Bejaia 06000, Algérie; n.adrar@hotmail.fr

4 Department of Plant Sciences, LCWU, Lahore 54000, Pakistan; shabnum_shaheen78@hotmail.com (S.S.); meh.jaffer@gmail.com (M.J.)

5 G.B. Pant National Institute of Himalayan Environment \& Sustainable Development Kosi-Katarmal, Almora 263 643, India; lalitorchid@gmail.com (L.G.); renusuyal04@gmail.com (R.S.)

6 G.B. Pant National Institute of Himalayan Environment \& Sustainable Development Garhwal Regional Centre, Srinagar 246174, India; arunjugran@gbpihed.nic.in

7 Department of Clinical Pharmacy, University of Medicine and Pharmacy of Craiova, 200349 Craiova, Romania; calinadaniela@gmail.com

8 Department of Toxicology, University of Medicine and Pharmacy of Craiova, 200349 Craiova, Romania; daoana00@gmail.com

9 Mevsim Gida Sanayi ve Soguk Depo Ticaret A.S. (MVSM Foods), Turankoy, Kestel, 16540 Bursa, Turkey; senemkamiloglu87@gmail.com

10 Institute of Fermentation Technology and Microbiology, Lodz University of Technology, Wolczanska 171/173, 90-924 Lodz, Poland; dorota.kregiel@p.lodz.pl (D.K.); hubert.antolak@p.lodz.pl (H.A.); ewelina.pawlikowska@edu.p.lodz.pl (E.P.)

11 Molecular and Applied Mycology and Plant Pathology Laboratory, Department of Botany, University of Calcutta, Kolkata 700019, India; surjitsen09@gmail.com (S.S.); krish_paper@yahoo.com (K.A.)

12 Department of Botany, Fakir Chand College, Diamond Harbour, West Bengal 743331, India

13 Department of Medical Biology, Faculty of Medicine, Nigde Ömer Halisdemir University, Campus, 51240 Nigde, Turkey; zselamoglu@ohu.edu.tr

14 Zabol Medicinal Plants Research Center, Zabol University of Medical Sciences, Zabol 61615-585, Iran

15 Department of Pharmacy, Faculty of Pharmacy, University of Concepcion, Concepcion 4070386, Chile

16 LEPABE, Department of Chemical Engineering, Faculty of Engineering, University of Porto, Rua Dr. Roberto Frias, s/n, 4200-465 Porto, Portugal; c.fortunae@gmail.com

17 Department of Pharmaceutical Technology, Avicenna Tajik State Medical University, Rudaki 139, Dushanbe 734003, Tajikistan; shfarukh@mail.ru

18 Faculty of Medicine, University of Porto, Alameda Prof. Hernâni Monteiro, 4200-319 Porto, Portugal

19 Institute for Research and Innovation in Health (i3S), University of Porto, 4200-135 Porto, Portugal

20 Department of Agricultural Sciences, University of Naples Federico II, 80055 Portici, Italy

* Correspondence: javad.sharifirad@gmail.com (J.S.-R.); martorellpons@gmail.com (M.M.); ncmartins@med.up.pt (N.M.); rafcapas@unina.it (R.C.); Tel.: +98-21-88200104 (J.S.-R.); +56-41-266-1671 (M.M.); +351-22-5512100 (N.M.); +39-081-678664 (R.C.)

Received: 2 April 2019; Accepted: 13 May 2019; Published: 14 May 2019 


\begin{abstract}
Cucurbita genus has received a renowned interest in the last years. This plant species, native to the Americas, has served worldwide folk medicine for treating gastrointestinal diseases and intestinal parasites, among other clinical conditions. These pharmacological effects have been increasingly correlated with their nutritional and phytochemical composition. Among those chemical constituents, carotenoids, tocopherols, phenols, terpenoids, saponins, sterols, fatty acids, and functional carbohydrates and polysaccharides are those occurring in higher abundance. However, more recently, a huge interest in a class of triterpenoids, cucurbitacins, has been stated, given its renowned biological attributes. In this sense, the present review aims to provide a detailed overview to the folk medicinal uses of Cucurbita plants, and even an in-depth insight on the latest advances with regards to its antimicrobial, antioxidant and anticancer effects. A special emphasis was also given to its clinical effectiveness in humans, specifically in blood glucose levels control in diabetic patients and pharmacotherapeutic effects in low urinary tract diseases.
\end{abstract}

Keywords: cucurbits; pumpkin; squash; antimicrobial; antioxidant; anticancer; traditional medicine

\title{
1. Introduction
}

Cucurbita plants have been applied in different cultures as traditional medication. For instance, Native Americans have used pumpkins for the treatment of intestinal worms and urinary ailments, this therapeutic strategy being approved by American doctors in the early nineteenth century as an anthelmintic for worms annihilating [1]. Seeds are used as an anthelmintic, to treat issues of the urinary framework, high blood pressure, to prevent the development of kidney stones, to ease prostate disorders and even to improve the erysipelas skin contamination [2]. In southeastern Europe, Cucurbita pepo L. (pumpkin) seeds have been applied to heal irritable bladder and prostate enlargement. Specifically, in Germany, the use of pumpkin seeds was adopted for application by the authority for irritated bladder conditions and micturition problems of prostate enlargement, although the monograph written in 1985 noted a lack of pharmacological studies that could confirm its effective clinical effects. On the other hand, in the USA, the purchase of all such non-prescription medications for the therapy of prostate enlargement was banned in 1990. In traditional Chinese medicine, Cucurbita moschata Duchesne seeds were also applied for handling the parasitic diseases caused by worms, while Mexican herbalists have used Cucurbita ficifolia Bouché as a remedy for reducing blood sugar levels [3-7].

Indeed, increasing evidence has shown that cucurbits' medicinal properties depend upon the chemical compounds present, which produce a specific physiological effect in the human body [8-10]. Specifically, cucurbits fruits are found to be beneficial in blood cleansing, purification of toxic substances and good for digestion, besides giving the required energy to improve human health. These species possess a higher amount of proteins, phytosterols [11,12], unsaturated fatty acids [13,14], vitamins (like carotenoids, tocopherols) [15] and microelements (e.g., zinc) [16]. Fruits, seeds and leaves from various Cucurbita members (pumpkin, watermelon, melon, cucumber squash, gourds, etc.) possess different pharmacological effects [17,18], such as antidiabetic [19-21], antiulcer, analgesic, nephroprotective [22] and anticancer activities [18]. In this sense, this review provides a detailed overview to the folk medicinal uses of Cucurbita plants, an in-depth insight on the latest advances regarding its antimicrobial, antioxidant and anticancer effects, and lastly, a special emphasis to its clinical effectiveness in humans, specifically in blood glucose levels control and low urinary tract diseases (Figure 1). 
PHYTOPHARMACEUTICAL

EFFECTS

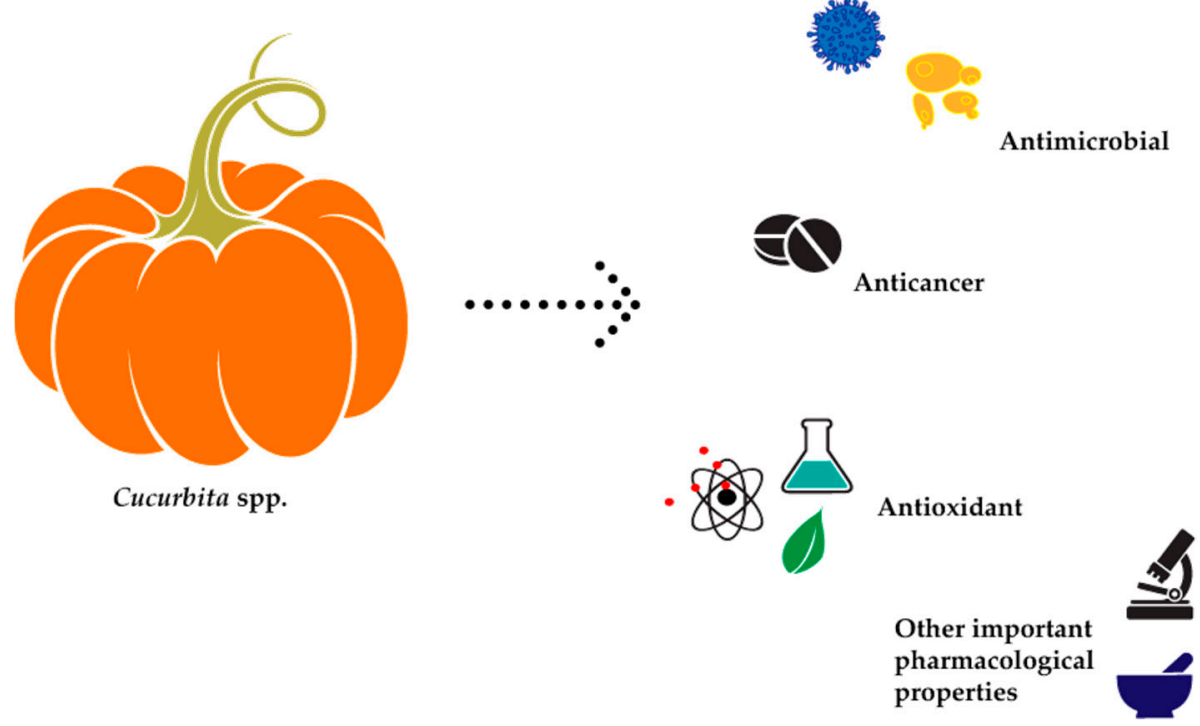

Figure 1. Most pronounced and investigated biological effects of Cucurbita spp.

\section{Cucurbita Plants: A Brief Overview to Its Ethnopharmacological Uses}

Recent ethnopharmacological studies showed that C. pepo and Cucurbita maxima Duchesne are among the most commonly used Cucurbita plants for traditional medicinal treatments. As shown in Table 1, many different components of Cucurbita plants are applied in diverse regions of the globe for handling different diseases.

Table 1. Cucurbita plants traditionally applied in the cures of different diseases in diverse regions of the world.

\begin{tabular}{|c|c|c|c|c|c|c|}
\hline $\begin{array}{l}\text { Scientific Name } \\
\text { (Common } \\
\text { Name) }\end{array}$ & Location & Local Name & Parts Used & Administration & $\begin{array}{l}\text { Disease(s) } \\
\text { Treatment }\end{array}$ & References \\
\hline \multirow{10}{*}{$\begin{array}{l}\text { Cucurbita } \\
\text { maxima } \\
\text { Duchesne } \\
\text { (Squash) }\end{array}$} & $\begin{array}{l}\text { Basque Country, } \\
\text { Iberian Peninsula }\end{array}$ & Kalabazea & Seeds & Oral & $\begin{array}{c}\text { Digestive } \\
\text { (Intestinal worms, } \\
\text { Constipation) }\end{array}$ & [23] \\
\hline & $\begin{array}{c}\text { Mkuranga District, } \\
\text { Tanzania }\end{array}$ & Maboga & Leaves & Oral & Anemia & {$[24]$} \\
\hline & $\begin{array}{l}\text { Polish people in } \\
\text { Misiones, Argentina }\end{array}$ & Zapallo & Seeds & Oral & $\begin{array}{l}\text { Intestinal } \\
\text { parasites }\end{array}$ & [25] \\
\hline & \multirow{2}{*}{$\begin{array}{c}\text { Nelliyampathy hills } \\
\text { of Kerala, India }\end{array}$} & \multirow[t]{2}{*}{ Parangi } & Seeds & Oral & $\begin{array}{l}\text { Vomiting blood, } \\
\text { Blood bile }\end{array}$ & \multirow[t]{2}{*}{ [26] } \\
\hline & & & Fruits & Oral & Urinal disorders & \\
\hline & Mauritius & Giromon & $\begin{array}{l}\text { Flowers } \\
\text { Seeds } \\
\text { Fruits }\end{array}$ & $\begin{array}{l}\text { Dermal } \\
\text { Oral } \\
\text { Dermal }\end{array}$ & $\begin{array}{c}\text { Cataract } \\
\text { Renal failure } \\
\text { Wound }\end{array}$ & [27] \\
\hline & $\begin{array}{c}\text { Agro Nocerino } \\
\text { Sarnese, Campania, } \\
\text { Southern Italy }\end{array}$ & Cocozza & Seeds & Oral & Prostatitis & [28] \\
\hline & India & UNSP & Flowers & UNSP & Osteosarcoma & [29] \\
\hline & $\begin{array}{c}\text { Pakistani descent in } \\
\text { Copenhagen, } \\
\text { Denmark }\end{array}$ & Kadoo & Fruits & Oral & $\begin{array}{l}\text { Blood pressure, } \\
\text { constipation }\end{array}$ & {$[30]$} \\
\hline & $\begin{array}{c}\text { Ashanti region, } \\
\text { Ghana }\end{array}$ & UNSP & Leaves & Oral & $\begin{array}{l}\text { Cancer (lung, } \\
\text { head) }\end{array}$ & [31] \\
\hline
\end{tabular}


Table 1. Cont.

\begin{tabular}{|c|c|c|c|c|c|c|}
\hline $\begin{array}{l}\text { Scientific Name } \\
\text { (Common } \\
\text { Name) }\end{array}$ & Location & Local Name & Parts Used & Administration & $\begin{array}{l}\text { Disease(s) } \\
\text { Treatment }\end{array}$ & References \\
\hline \multirow[t]{9}{*}{$\begin{array}{l}\text { Cucurbita pepo L. } \\
\text { (Pumpkin) }\end{array}$} & $\begin{array}{l}\text { Ghimbi District, } \\
\text { Southwest Ethiopia }\end{array}$ & Buqqee & Seeds & Oral & Gonorrhea & [32] \\
\hline & $\begin{array}{c}\text { Mexico, Central } \\
\text { America, Caribbean }\end{array}$ & Calabaza & Whole plant & Oral & Obesity & [33] \\
\hline & $\begin{array}{l}\text { Ripollès district, } \\
\text { Pyrenees, Catalonia, } \\
\text { Iberian Peninsula }\end{array}$ & Carbassa & Flowers & Dermal & $\begin{array}{l}\text { Acne, Dermatitis, } \\
\text { Ecchymosis, Fever, } \\
\text { Toxicity, Wound }\end{array}$ & [34] \\
\hline & & & Fruits & Dermal & Infection & \\
\hline & $\begin{array}{l}\text { Nkonkobe } \\
\text { Municipality, } \\
\text { Eastern Cape, } \\
\text { South Africa }\end{array}$ & Imithwane & Leaves & Oral & $\begin{array}{l}\text { Arthritis, Blood } \\
\text { booster }\end{array}$ & [35] \\
\hline & West Bank, Palestine & Kare'a & Seeds & Oral & Breast cancer & [36] \\
\hline & $\begin{array}{l}\text { Delanta, } \\
\text { Northwestern Wello, } \\
\text { Northern Ethiopia }\end{array}$ & UNSP & Fruits & Oral & $\begin{array}{l}\text { Gastritis, } \\
\text { Stomachache }\end{array}$ & [37] \\
\hline & & & Leaves & Dermal & Dandruff & \\
\hline & $\begin{array}{c}\text { Local Government } \\
\text { Area, } \\
\text { south-eastern } \\
\text { Nigeria }\end{array}$ & Okeugu & Leaves & Oral & Malaria & [38] \\
\hline $\begin{array}{l}\text { Cucurbita } \\
\text { galeottii Cogn. } \\
\text { (Pumpkin) }\end{array}$ & Mauritius & Giraumon & Seeds & Oral & Mucous discharge & [39] \\
\hline
\end{tabular}

UNSP: Unspecified.

In particular, the positive health effects of C. maxima seeds are well-documented [23,25-28]. Raw C. maxima seeds are orally administered for the treatment of digestive disorders, such as intestinal worms [23,25], constipation [23] and vomiting blood and blood bile [26] by the local people in the Iberian Peninsula, Argentina and India, respectively. Also, sun-dried seeds of C. maxima are ingested in Mauritius for the treatment of renal failure [27], whereas raw seeds are consumed to treat prostatitis in the Agro Nocerino Sarnese in Campania, Southern Italy [28]. C. maxima seeds, fruits, flowers and leaves are also used as traditional medicine $[24,26,27,29-31]$, where the treatment of urinary disorders, blood pressure regulation and prevention of constipation can be achieved with oral consumption of C. maxima fruits, and the wound healing with dermal application [26,27,30]. In Mkuranga district in Tanzania, C. maxima leaves are used for healing anemia [24], and in the Ashanti region in Ghana, this plant part is orally consumed for lung and head cancer treatment [31]. Furthermore, in Mauritius, C. maxima fruits are compressed externally on eyes against cataract [27], while in India the same petals are used to treat osteosarcoma [29]. Nonetheless, and to the authors knowledge, much is needed to support both the in vitro and in vivo biological effects of this plant, since most of the efforts has been made towards its agro-industrial applications.

With regards to $C$. pepo seeds, they are mainly regarded as agro-industrial wastes, while in some parts of the globe they are used raw, roasted or cooked, at a domestic scale [40]. Accordingly, in a study carried out in Ghimbi District in Southwest Ethiopia [32], it was reported that oral administration of cultivated seed of C. pepo is used as a gonorrhea therapy. Moreover, C. pepo seeds are also used as an herbal remedy by breast cancer patients in West Bank in Palestine [36]. In another study, conducted in Nkonkobe municipality in Eastern Cape, South Africa [35], it was indicated that arthritis and blood booster are treated with orally taken C. pepo leaves. C. pepo leaves are also used for the treatment of malaria and dandruff in the local government area in south-eastern Nigeria and Ghimbi District in Southwest Ethiopia, respectively $[37,38]$. In the latter study, it was also pointed out that the fruits of C. pepo are consumed to treat gastritis and stomachache [37]. Topical use of $C$. pepo fruit as an external antiseptic was reported in Ripollès district, the Pyrenees in Catalonia and Iberian Peninsula, whereas in the same location the flowers of this plant are used for antigenic, antidermatitic, antiecchymotic, antiophidian, antipyretic and anti-toxic purposes [34]. C. pepo, as the whole plant, is also applied in the 
folk medicine of Mesoamerica and Caribbean for the therapy of fitness due to its pancreatic lipase inhibition activity [33]. In addition to the above, the decoction prepared from the Cucurbita galeottii Cogn. seeds is used against mucous discharge in Mauritius [39].

\section{Cucurbita Plants Phytochemical Composition}

Carotenoids are highly present in the fruit of these plants, namely $\alpha$-carotene, $\beta$-carotene, $\zeta$-carotene, neoxanthin, violaxanthin, lutein, zeaxanthin, taraxanthin, luteoxanthin, auroxanthine, neurosporene, flavoxanthin, 5,6,5',6'-diepoxy- $\beta$-carotene, phytofluene, $\alpha$-cryptoxanthin and $\beta$-cryptoxanthin [41]. Total carotenoid content varied between $234.21 \mu \mathrm{g} / \mathrm{g}$ to $404.98 \mu \mathrm{g} / \mathrm{g}$ in C. moschata fruit [42], and $171.9 \mu \mathrm{g} / \mathrm{g}$ to $461.9 \mu \mathrm{g} / \mathrm{g}$ in C. pepo fruit [43]. There are also several publications on the carotenoid content of a number of Cucurbita plants such as C. moschata, C. pepo [42] and C. maxima [44]. Edible Cucurbita seeds are also rich in vitamin E $(49.49 \mu \mathrm{g} / \mathrm{g}$ to $92.59 \mu \mathrm{g} / \mathrm{g}), \gamma$-tocopherol is more abundant than $\alpha$-tocopherol and the fruit contains less [45].

The study of Yang et al. [46] showed no flavonoid content (below detection limit: $0.05 \mathrm{mg} / 100 \mathrm{~g}$ ) in either the immature or the mature fruit of $C$. maxima. Only the shoots and buds showed positive results. Sreeramulu and Raghunath [47] reported that average total phenolic content of $C$. maxima was $46.43 \mathrm{mg}$ gallic acid equivalent (GAE)/100 g. In another study, C. maxima was analyzed for its flavonoid content and kaempferol was found to be the only flavonoid in this species at a concentration of $371.0 \mathrm{mg} / \mathrm{kg}$ of dry weight [48].

C. pepo was found to be very weak in polyphenol content. Only $0.02 \mathrm{mg}$ GAE/100 mg sample has been found in its fresh fruit by Mongkolsilp et al. [49]. However, Iswaldi et al. [50] have reported for the first time a list of 34 polyphenols including a variety of flavonoids in the fruit of C. pepo., in addition to other unknown polar compounds. Besides, the flowers of C. pepo may contain considerable amount of phenolic compounds. Andjelkovic et al. [51] studied the phenolic content of six pumpkin (C. pepo) seed oils and identified the following compounds: Tyrosol, vanillic acid, vanillin, ferulic acid and luteolin. Among them, tyrosol was the most abundant compound ranging from $1.6 \mathrm{mg} / \mathrm{kg}$ to $17.7 \mathrm{mg} / \mathrm{kg}$.

Peričin et al. [52] studied the phenolic acid content of C. pepo seeds. $p$-Hydroxybenzoic acid was found to be the prevailing phenolic acid, with $34.72 \%, 67.38 \%$ and $51.80 \%$ of the total phenolic acid content in whole dehulled seed, kernels and hulls, respectively. Aside from p-hydroxybenzoic acid, the most dominant phenolic compounds can be listed in a decreasing order of quantity as follows: Caffeic, ferulic and vanillic acids in whole dehulled seeds. Trans-synapic and protocatechuic acids, and $p$-hydroxybenzaldehyde were the abundant phenolic acids presented in the kernels of hulled pumpkin variety; the hulls comprised p-hydroxybenzaldehyde, vanillic and protocatechuic acids with considerable amounts. Table 2 presents the main phenolic compounds found in the Cucurbita spp. and their structures. 
Table 2. Main chemical structures of the phenolic compounds found in the Cucurbita spp.*.

\begin{tabular}{|c|c|c|c|c|}
\hline Compound Name & Synonym(s) & Empirical Formula & Structure & References \\
\hline Protocatechuic acid & 3,4-Dihydroxybenzoic acid & $\mathrm{C}_{7} \mathrm{H}_{6} \mathrm{O}_{4}$ & & $\begin{array}{c}{[52]} \\
\text { http://phenol-explorer.eu/ } \\
\text { compounds/412 }\end{array}$ \\
\hline$p$-Hydroxybenzoic acid & 4-Hydroxybenzoic acid & $\mathrm{C}_{7} \mathrm{H}_{6} \mathrm{O}_{3}$ & & $\begin{array}{c}{[52]} \\
\text { http://phenol-explorer.eu/ } \\
\text { compounds/418 }\end{array}$ \\
\hline$p$-Hydroxybenzaldehyde & 4-Hydroxybenzaldehyde & $\mathrm{C}_{7} \mathrm{H}_{6} \mathrm{O}_{2}$ & & $\begin{array}{c}{[52]} \\
\text { http://phenol-explorer.eu/ } \\
\text { compounds/725 }\end{array}$ \\
\hline Vanillic acid & $\begin{array}{l}\text { 4-Hydroxy-3-methoxybenzoic } \\
\text { acid; } p \text {-Vanillic acid }\end{array}$ & $\mathrm{C}_{8} \mathrm{H}_{8} \mathrm{O}_{4}$ & & $\begin{array}{c}{[52]} \\
\text { http://phenol-explorer.eu/ } \\
\text { compounds/414 }\end{array}$ \\
\hline
\end{tabular}


Table 2. Cont.

\begin{tabular}{|c|c|c|c|c|}
\hline Compound Name & Synonym(s) & Empirical Formula & Structure & References \\
\hline Caffeic acid & 3,4-Dihydroxycinnamic acid & $\mathrm{C}_{9} \mathrm{H}_{8} \mathrm{O}_{4}$ & & $\begin{array}{c}\text { [52] } \\
\text { http://phenol-explorer.eu/ } \\
\text { compounds/457 }\end{array}$ \\
\hline Syringic acid & 3,5-Dimethoxy-4-hydroxybenzoic acid & $\mathrm{C}_{9} \mathrm{H}_{10} \mathrm{O}_{5}$ & & $\begin{array}{c}\text { [52] } \\
\text { http://phenol-explorer.eu/ } \\
\text { metabolites/420 }\end{array}$ \\
\hline trans-p-coumaric acid & trans-4-Hydroxycinnamic acid & $\mathrm{C}_{9} \mathrm{H}_{8} \mathrm{O}_{3}$ & & $\begin{array}{c}\text { [52] } \\
\text { http://phenol-explorer.eu/ } \\
\text { compounds/454 }\end{array}$ \\
\hline Ferulic acid & $\begin{array}{l}\text { 3-Methoxy-4-Hydroxycinnamic acid; } \\
\text { 3-Methylcaffeic acid; Coniferic acid }\end{array}$ & $\mathrm{C}_{10} \mathrm{H}_{10} \mathrm{O}_{4}$ & & $\begin{array}{c}{[52]} \\
\text { http://phenol-explorer.eu/ } \\
\text { compounds/459 }\end{array}$ \\
\hline
\end{tabular}


Table 2. Cont.

\begin{tabular}{|c|c|c|c|c|}
\hline Compound Name & Synonym(s) & Empirical Formula & Structure & References \\
\hline trans-sinapic acid & $\begin{array}{l}\text { trans-4-Hydroxy-3,5-dimethoxy-cinnamic } \\
\text { acid; trans-Sinapinic acid }\end{array}$ & $\mathrm{C}_{11} \mathrm{H}_{12} \mathrm{O}_{5}$ & $\mathrm{OCH}_{3}$ & $\begin{array}{c}\text { [52] } \\
\text { http://phenol-explorer.eu/ } \\
\text { compounds/464 }\end{array}$ \\
\hline Tyrosol & $\begin{array}{l}\text { p-HPEA; 4-(2-Hydroxyethyl)phenol; } \\
\text { 2-(4-Hydroxyphenyl)ethanol; } \\
\text { 2,4-Hydroxyphenyl-ethyl-alcohol; } \\
\text { 4-Hydroxyphenylethanol }\end{array}$ & $\mathrm{C}_{8} \mathrm{H}_{10} \mathrm{O}_{2}$ & & $\begin{array}{c}\text { [52] } \\
\text { http://phenol-explorer.eu/ } \\
\text { compounds/673 }\end{array}$ \\
\hline Vanillin & $\begin{array}{l}\text { 4-Hydroxy-3-methoxy-benzoic aldehyde; } \\
\text { Methylprotocatechuic aldehyde; } \\
\text { Vanillic aldehyde; } p \text {-Vanillin }\end{array}$ & $\mathrm{C}_{8} \mathrm{H}_{8} \mathrm{O}_{3}$ & & $\begin{array}{c}\text { [52] } \\
\text { http://phenol-explorer.eu/ } \\
\text { compounds/724 }\end{array}$ \\
\hline
\end{tabular}


Table 2. Cont.

\begin{tabular}{|c|c|c|c|c|}
\hline Compound Name & Synonym(s) & Empirical Formula & Structure & References \\
\hline Luteolin & $5,7,3^{\prime}, 4^{\prime}$-Tetrahydroxyflavone & $\mathrm{C}_{15} \mathrm{H}_{10} \mathrm{O}_{6}$ & & $\begin{array}{c}{[52]} \\
\text { http://phenol-explorer.eu/ } \\
\text { compounds/229 }\end{array}$ \\
\hline Kaempferol & 3,5,7,4'-Tetrahydroxyflavone & $\mathrm{C}_{15} \mathrm{H}_{10} \mathrm{O}_{6}$ & & $\begin{array}{c}{[52]} \\
\text { http://phenol-explorer.eu/ } \\
\text { compounds/290 }\end{array}$ \\
\hline
\end{tabular}

* The data were collected from the Phenol-Explorer database, which is an online comprehensive database on polyphenol contents in foods, http://phenol-explorer.eu/ (Accessed on 09.12.2018). 


\section{Looking at Cucurbita Plants Biological Activity}

\subsection{Antimicrobial Activity of Cucurbita Plants}

\subsubsection{In Vitro Studies}

Pumpkin extracts showed a positive activity towards bacterial and fungal infections. They were effective against gram-positive: Staphylococcus aureus, Bacillus subtilis, as well as gram-negative bacterium: Escherichia coli, Proteus vulgaris, Pseudomonas aeruginosa, Salmonella spp. or Klebsiella spp. Pumpkin extracts also showed antibacterial activity against water borne bacteria Vibrio cholerae as well as intestinal flagellated parasite Giardia lamblia, often isolated from surface water. Other studies documented that pumpkin extracts showed a wide range of antifungal activity against species from the Fusarium, Trichoderma, Aspergillus, Verticillium, Phytophora, Botrytis, Candida and Saccharomyces genera (Table 3). However, the mechanisms of antimicrobial activity of pumpkin extracts are still unknown, although it seems to exist a synergistic action between all extracted bioactive substances. It is well known that plant extracts exert biological effects more prominent than their isolated compounds. In fact, recent evidence has established that, in whole matrices, the major compounds interact with those in trace amounts to potentiate their own potential, to provide additional properties other than those often recommended and even to help counterbalance the side effects of these isolated compounds. In addition, and not the least important to emphasize, is that such minor compounds by strengthening the biological effects of a specific bioactive also reduces the dose required to achieve a similar effect.

Table 3. Antimicrobial activity of Cucurbita spp. extracts evaluated in vitro.

\begin{tabular}{|c|c|c|c|}
\hline Cucurbita spp./Plant Part & Extract & Microbial & References \\
\hline $\begin{array}{l}\text { Cucurbita pepo L. } \\
\text { fruits }\end{array}$ & Water & Escherichia coli & [53] \\
\hline $\begin{array}{l}\text { Cucurbita pepo L. } \\
\text { fruits }\end{array}$ & Methanol & $\begin{array}{c}\text { Bacillus cereus } \\
\text { Bacillus subtilis } \\
\text { Escherichia coli } \\
\text { Enterobacter aerogenes } \\
\text { Enterobacter agglomerans } \\
\text { Salmonella enteritidis } \\
\text { Salmonella choleraesuis } \\
\text { Staphylococcus aureus } \\
\text { Pseudomonas aeruginosa } \\
\text { Enterobacter faecalis } \\
\text { Klebsiella pneumoniae } \\
\text { Bacillus sphericus } \\
\text { Bacillus thruengenesis } \\
\text { Cryptococcus meningitis } \\
\text { Penicillium chrysogenum }\end{array}$ & {$[54]$} \\
\hline Cucurbita pepo L. & $\begin{array}{c}\text { Phosphate buffered } \\
\text { saline (PBS) }\end{array}$ & $\begin{array}{c}\text { Serratia marcescens } \\
\text { Escherichia coli } \\
\text { Streptococcus thermophilous } \\
\text { Fusarium oxysporium } \\
\text { Trichoderma reesei } \\
\text { Aspergillus niger }\end{array}$ & [55] \\
\hline $\begin{array}{l}\text { Cucurbita pepo L. } \\
\text { fruits }\end{array}$ & Ethanol extract & Heligmosoides bakeri (worm) & {$[56]$} \\
\hline $\begin{array}{l}\text { Cucurbita pepo L. } \\
\text { cortex }\end{array}$ & Water, methanol & $\begin{array}{c}\text { Staphylococcus aureus } \\
\text { Escherichia coli } \\
\text { Proteus mirabilis } \\
\text { Klebsiella pneumoniae }\end{array}$ & [57] \\
\hline
\end{tabular}


Table 3. Cont.

\begin{tabular}{|c|c|c|c|}
\hline Cucurbita spp./Plant Part & Extract & Microbial & References \\
\hline $\begin{array}{l}\text { Cucurbita pepo L. } \\
\text { seeds, backpeel }\end{array}$ & $\begin{array}{l}\text { Methanol, } \\
\text { ethanol }\end{array}$ & $\begin{array}{l}\text { Staphylococcus aureus } \\
\text { Salmonella typhi }\end{array}$ & [58] \\
\hline $\begin{array}{l}\text { Cucurbita pepo L. } \\
\text { leaves }\end{array}$ & Ethanol & $\begin{array}{c}\text { Serratia sp. } \\
\text { Escherichia coli } \\
\text { Klebsiella pneumoniae } \\
\text { Bacillus subtilis }\end{array}$ & [59] \\
\hline $\begin{array}{l}\text { Cucurbita pepo L. } \\
\text { leaves }\end{array}$ & Methanol & $\begin{array}{c}\text { Providencia stuartii } \\
\text { Pseudomonas aeruginosa } \\
\text { Klebsiella pneumoniae } \\
\text { Escherichia coli } \\
\text { Enterobacter aerogenes } \\
\text { Enterobacter cloacae }\end{array}$ & [60] \\
\hline $\begin{array}{l}\text { Cucurbita pepo L. } \\
\text { leaves }\end{array}$ & $\begin{array}{c}\text { Ethyl acetate, n-butanol, } \\
\text { water }\end{array}$ & $\begin{array}{c}\text { Bacillus subtilis } \\
\text { Pseudomonas aeruginosa } \\
\text { Staphylococcus aureus }\end{array}$ & {$[61]$} \\
\hline $\begin{array}{l}\text { Cucurbita moschata Duchesne } \\
\text { seeds oil extract }\end{array}$ & Methanol & $\begin{array}{c}\text { Candida albicans } \\
\text { Rhodotorula rubra } \\
\text { Trichoderma viride } \\
\text { Penicillium chrysogenum } \\
\text { Rhizopus oligosporus }\end{array}$ & [62] \\
\hline $\begin{array}{l}\text { Cucurbita moschata Duchesne } \\
\text { crude protein from rinds, seeds } \\
\text { and pulp }\end{array}$ & Acetone & $\begin{array}{c}\text { Aspergillus fumigatus } \\
\text { Aspergillus parasiticus } \\
\text { Aspergillus niger } \\
\text { Staphylococcus aureus } \\
\text { Bacillus subtilis } \\
\text { Klebsiella pneumoniae } \\
\text { Pseudomonas aeruginosa } \\
\text { Escherichia coli }\end{array}$ & [62] \\
\hline $\begin{array}{l}\text { Cucurbita maxima Duchesne } \\
\text { fruit }\end{array}$ & $\begin{array}{l}\text { Petroleum ether and } \\
\text { methanol }\end{array}$ & Giardia lamblia & [63] \\
\hline $\begin{array}{l}\text { Cucurbita maxima Duchesne } \\
\text { flowers }\end{array}$ & Alcohol & $\begin{array}{l}\text { Salmonella typhi, } \\
\text { Escherichia coli } \\
\text { Enterobacter faecalis, } \\
\text { Bacillus cereus } \\
\text { Curvularia lunata } \\
\text { Candida albicans }\end{array}$ & [64] \\
\hline $\begin{array}{l}\text { Cucurbita maxima Duchesne } \\
\text { peels }\end{array}$ & Water & $\begin{array}{l}\text { Escherichia coli } \\
\text { Pseudomonas sp. } \\
\text { Vibrio cholerae }\end{array}$ & [65] \\
\hline $\begin{array}{c}\text { Cucurbita maxima Duchesne } \\
\text { seeds }\end{array}$ & Ethanol & $\begin{array}{c}\text { Entamoeba histolytica } \\
\text { Staphylococcus aureus } \\
\text { Bacillus subtilis } \\
\text { Pseudomonas aeruginosa } \\
\text { Escherichia coli } \\
\text { Candida albicans } \\
\text { Aspergillus niger }\end{array}$ & {$[66]$} \\
\hline $\begin{array}{l}\text { Cucurbita maxima Duchesne } \\
\text { seeds }\end{array}$ & Ethanol & $\begin{array}{c}\text { Staphylococcus aureus } \\
\text { Bacillus subtilis } \\
\text { Staphylococcus werneri } \\
\text { Pseudomonas putida } \\
\text { Pseudomonas aeruginosa } \\
\text { Proteus mirabilis } \\
\text { Escherichia coli } \\
\text { Kleibsella pneumoniae }\end{array}$ & [67] \\
\hline
\end{tabular}




\subsubsection{In Vivo Studies}

Not only pumpkin extracts, but also proteins and peptides isolated from Cucurbita spp. were identified and characterized in terms of antimicrobial activity. Three pumpkin proteins inhibited the growth of fungi Fusarium oxysporum, Verticillium dahliae and Saccharomyces cerevisiae [68]. The antifungal peptide-cucurmoschin - isolated from black pumpkin seeds also demonstrated inhibitory activity against mold growth: Botrytis cinerea, F. oxysporum and Mycosphaerella oxysporum [69]. The ribosome-inactivating protein extracted from $C$. moschata showed an antimicrobial effect towards phytopathogenic fungi Phytophora infestans as well as against bacteria Pseudomonas solanacearum and Erwinia amylovora [70]. Additionally, PR-5 protein isolated from leaves of pumpkin, demonstrated synergism with combination of nikkomycin, a chitin synthase inhibitor, towards to Candida albicans [71]. Protein Pr-1 isolated from pumpkin rind inhibited the growth of plant pathogenic fungi, namely B. cinerea, F. oxysporum, F. solani and Rhizoctonia solani, as well as the opportunistic pathogenic yeast C. albicans [72]. These results demonstrate that the proteins from pumpkin may be of importance to clinical microbiology with a wide range of therapeutic applications (Table 4). As the most prominent ones, and given the current evidence, namely regarding its ability to trigger fungal membranes damages and to improve the plasma membranes permeability, they can be effectively used to combat fungal infections and even to use in combination with current antifungal agents, both to improve its effectiveness and even to reduce its side effects.

Table 4. In vitro antimicrobial activity of Cucurbita spp. proteins.

\begin{tabular}{|c|c|c|}
\hline Cucurbita spp. Proteins & Microbial & References \\
\hline Cucurbita maxima Duchesne seeds proteins & $\begin{array}{c}\text { Fusarium oxysporum, } \\
\text { Verticillium dahliae } \\
\text { Saccharomyces cerevisiae }\end{array}$ & [68] \\
\hline Cucurbita maxima Duchesne seeds protein RIP & $\begin{array}{c}\text { Phytophora infestans, } \\
\text { Erwinia amylovora, } \\
\text { Pseudomonas solanacearum }\end{array}$ & [70] \\
\hline Pumpkin leaves protein PR-5 & Candida albicans & [71] \\
\hline Pumpkin rind protein Pr-1 & $\begin{array}{l}\text { Botrytis cinerea, } \\
\text { Fusarium oxysporum, } \\
\text { Fusarium solani } \\
\text { Rhizoctonia solani, } \\
\text { Candida albicans }\end{array}$ & [72] \\
\hline Black pumpkin seeds protein cucurmoschin & $\begin{array}{c}\text { Botrytis cinerea, } \\
\text { Fusarium oxysporum } \\
\text { Mycosphaerella oxysporum }\end{array}$ & [69] \\
\hline
\end{tabular}

Pumpkin pulp, due to its antimicrobial properties, is widely used to relieve intestinal inflammation or stomach disorders [73] (Table 5). Pumpkin and its seeds, in the traditional world medicine, are often employed as an anti-helminthic remedy and for supportive therapy in functional diseases of the bladder as well as in the case of digestion problems. The usage of an extract of C. pepo cortex towards urinary tract infections may correspond to a new source of antibiotics against bacterial urinary tract infections [57]. Other studies represented the importance of oil from seeds of a pumpkin as a hopeful drug for treating wounds in vivo [74]. The researchers demonstrated a premium quality of pumpkin oil with a high quantity of polyunsaturated fatty acids, tocopherols that were able to perform efficient wound healing [74]. Morphometric evaluation and histological evidence in rats showed healed biopsies from pumpkin oil and a complete re-epithelialization with a recurrence of skin appendages and well re-growing collagen fibers out of cells inflammation.

Pumpkin-based foodstuff is well recognized as a source of anti-inflammatory remedies, which can be useful in arthritis treatment [75]. Pumpkin seed oil notably prevent adjuvant-induced arthritis 
in rats, similar to indomethacin, a well-known anti-inflammatory substance. Its clinical applicability as an antioxidant was also assessed on rheumatoid arthritis [76] and recently confirmed by Dixon [77].

Table 5. Antimicrobial property of Cucurbita spp. and its importance in vivo.

\begin{tabular}{ccc}
\hline & Antimicrobial Property & References \\
\hline Cucurbita pepo L. seeds & Wounds healing & {$[74]$} \\
\hline Pumpkin seeds & $\begin{array}{c}\text { Anthelmintic, treatment of bladder } \\
\text { functional disorders }\end{array}$ & {$[78]$} \\
\hline Pumpkin seed oil & Arthritis prevention & {$[75]$} \\
\hline Pumpkin fruits & $\begin{array}{c}\text { Control of gastrointestinal } \\
\text { nematode infections }\end{array}$ & {$[56]$} \\
\hline Cucurbita pepo L. cortex extract & $\begin{array}{c}\text { Effective treatment of bacterial } \\
\text { urinary tract infections }\end{array}$ & {$[57]$} \\
\hline
\end{tabular}

\subsection{Anticancer Activities of Cucurbita Plants}

Cucurbitacins are a unique gathering of triterpenoids that containing a cucurbitane basic structure skeleton, and an extensive variety of natural exercises is related with their substance basic multifaceted nature. Cucurbitacins have been accounted for the most secondary metabolites in the Cucurbitaceae. They have the biogenetically $10 \alpha$-cucurbit-5-ene $[19(10 \rightarrow 19 \beta)$ abeo-10 $\alpha$-lanostane skeleton, which is related to their cytotoxicity. A few reports credited in vitro and in vivo cytotoxic exercises to the cucurbitacins [79,80]. Jayaprakasam et al. [81] exhibited the anticancer properties of cucurbitacins B, D, E and I, confined from the products of Cucurbita andreana Naudin, towards colon, bosom, lung and focal sensory system disease cell lines. Cucurbitacin B is the most considered and keeping in mind that few investigations exhibited its viability in various models of malignant growth, incorporating into vivo tumor xenografts [82-85], there is a contradiction concerning the components hidden its anticancer action. Concealment of the oncogene STAT 3 (signal transducer and activator of transcription 3) has all the earmarks of being identified with tumor restraint [86], which does not prohibit elective. A malignant growth is in charge of $12 \%$ of the global impermanence. Medications incorporate chemotherapy medical procedure and radiation therapy. Be that as it may, chemotherapy endures constraints of medication obstruction, poisonous quality, reactions and lacking explicitness toward tumor cells [87]. Consequently, there is a solid enthusiasm for the utilization of plants as a promising wellspring of increasingly productive anticancer medications.

\section{In Vitro Anticancer/Antitumor Effects}

Presently over forty cucurbitacins have been isolated from the Cucurbitaceae family and different types of the herbs. The apoptotic impacts of cucurbitacins are expected of their capacity to change the qualities, transcriptional exercises using atomic components and mitochondrial trans-film potential and their ability to initiate or hinder ace or hostile to apoptotic proteins. Cucurbitacins are specific inhibitors of the JAK/STAT pathways; likewise, different instruments are involved in their apoptotic impacts, for example, PARP cleavage, MAPK pathway, articulation of dynamic caspase-3, diminished JAK3 and pSTAT3 levels and also diminishes in different downstream STAT3 targets, for example, Bcl-2, Mcl-1, cyclin D3 and BclxL, which are all embroiled in the cell cycle control [88].

C. pepo alcohol extract demonstrated cytotoxicity towards HepG2 and CT26 cell lines with $\mathrm{IC}_{50}$ values $132.6 \mu \mathrm{g} / \mathrm{mL}$ and $167.2 \mu \mathrm{g} / \mathrm{mL}$, individually. The ethanol extract of $C$. pepo was displayed a huge portion subordinate inhibitory impact towards HeLa cell development [89].

Cucurbita glycosides A and B isolated from C. pepo ethanol extract demonstrated cytotoxic action in vitro towards HeLa cells with $\mathrm{IC}_{50} 17.2 \mu \mathrm{g} / \mathrm{mL}$ and $28.5 \mu \mathrm{g} / \mathrm{mL}$, individually [90]. Cucurbitacin B and E isolated from C. pepo cv dayangua demonstrated an antiproliferative in MCF-7, HCT-116, SF-268, A549 and NCI-H460 cell lines [81]. 
The antiproliferative impact of 23,24-dihydrocucurbitacin F, on human PCa cells may jump out at the enlistment of the cofilin-actin pole development and actin collection delivering to cell cytokinesis disappointment, hindered cell development cycle capture at G2/M stage and apoptosis [91]. Likewise, 23,24-dihydrocucurbitacin F has an inhibitory effect on Epstein-Barr infection actuation initiated by the tumor advertiser, 12-O-tetradecanoyl-phorbol-13-acetic acid derivation and furthermore, shows altogether hostile to tumor-advancement action on mouse skin tumor advancement [88].

Treatment with cucurbitacins B and E resulted in apoptosis and cell cycle capture of MDAMB-231 and MCF-7 breast cancer cell lines. Additionally, they tweaked the outflow of proteins associated with cell-cycle control in both of the estrogen-autonomous (MDA-MB-231) and estrogen-subordinate (MCF-7) in human bosom malignant growth cell lines. Growth hindrance and cytotoxic impact of cucurbitacin B on bosom disease cell lines SKBR-3 and MCF-7 were credited to G2/M stage capture and apoptosis. Cucurbitacin B treatment repressed Cyclin D1, c-Myc and $\beta$-catenin articulation levels, translocation to the core of $\beta$-catenin and galectin-3. Western smear investigation demonstrated expanded PARP cleavage proposing actuated caspase action and diminished mitogenic Wnt-related flagging particles galectin-3, $\beta$-catenin, c-Myc and cyclin D1 with changes in phosphorylated GSK-3 $\beta$ levels [92].

Cucurbitacin E caused disturbance of the cytoskeleton structure of actin and vimentin inhibiting the multiplication of prostate disease cells. Cucurbitacins also additionally hindered the expansion of endothelial cells joined by an interruption of the F-actin and tubulin microfilaments cytoskeleton, typical mitogen-prompted T-lymphocytes and lessened cell motility recommend an enemy of angiogenesis and hostile to the metastasis job for cucurbitacins. It is also fit for instigating and keeping up high multiplication rates in lymphocytes [93].

The literature has indicated that secondary metabolites of $C$. pepo have the potential anticancer activity, which represents great interest for the development of new chemotherapeutic agents for preventive growth of the tumor.

\section{Clinical Effectiveness of Cucurbita Plants in Humans}

\subsection{Control of Blood Glucose Level in Diabetic Patients}

Diabetes mellitus is a chronic disease characterized by changes in saccharide, lipid and protein metabolism resulting from a deficiency in insulin secretion from the pancreas, insulin resistance or both. The main clinical symptom is represented by increased blood sugar levels (hyperglycemia) that uncontrolled lead in time to a wide spectrum of complications [94]. Natural therapeutic alternatives to allopathic treatment always attracted the researchers to the intention of finding new drugs with fewer side effects [95-100]. Thus, the hypoglycemic effect of Cucurbita species (Table 6) is known and used for long traditional medicine in many countries, like China, India, Iran and Mexico [101-104].

Table 6. Pharmacotherapeutic effects of Cucurbita plants in human clinical studies.

\begin{tabular}{|c|c|c|c|}
\hline & Part of the Plant with Active Compounds & Cucurbita spp. & References \\
\hline \multirow{2}{*}{ Hypoglycemic } & Polysaccharides from pulp fruit & $\begin{array}{c}\text { Cucurbita maxima } \\
\text { Duchesne } \\
\text { Cucurbita ficifolia Bouché }\end{array}$ & {$[105,106]$} \\
\hline & $\begin{array}{l}\text { Non-pectines polysaccharides and pectines } \\
\text { from pulp; proteins and oil from seeds }\end{array}$ & Cucurbita ficifolia Bouché & [107-109] \\
\hline $\begin{array}{l}\text { Reduced clinical symptoms of } \\
\text { benign prostatic hyperplasia }\end{array}$ & $\begin{array}{l}\Delta 5-\Delta 7-\Delta 8 \text {-Phytosterols, unsaturated fatty } \\
\text { acids from seeds extracts, lignans }\end{array}$ & Cucurbita pepo L. & [110-113] \\
\hline $\begin{array}{l}\text { Positive effects in stress urinary } \\
\text { incontinence in female }\end{array}$ & Oil, sterols from seeds & Cucurbita pepo L. & {$[114,115]$} \\
\hline \multirow{2}{*}{$\begin{array}{l}\text { Improved urinary symptoms in } \\
\text { human overactive bladder }\end{array}$} & \multirow{2}{*}{$\begin{array}{l}\text { Seeds oil (sterols) blended with soy germ } \\
\text { extract (phenols, isoflavones) }\end{array}$} & Cucurbita pepo L. & {$[116]$} \\
\hline & & $\begin{array}{l}\text { Cucurbita maxima } \\
\text { Duchesne }\end{array}$ & {$[117]$} \\
\hline
\end{tabular}


Mahmoodpoor et al. [106] in a recent study performed on patients with severe diabetes from the Intensive Care Unit showed the hypoglycemic effect of $C$. maxima pulp. The subjects received five grams of $C$. maxima powder per $12 \mathrm{~h}$ for three consecutive days. After the treatment, it was observed a decrease of serum glucose levels from $214.9 \mathrm{mg} / \mathrm{dL}$ to $214.9 \mathrm{mg} / \mathrm{dL}$ associated with a reduction of insulin doses from 48.05 IU to 39.5 IU [106]. C. ficifolia also showed a good hypoglycemic effect when the extract was administered in doses of $4 \mathrm{~mL} / \mathrm{kg}$ to patients with type 2 diabetes and moderately elevated blood glucose level [105]. Five hours after administration, the mean of serum glucose level decreased from $217.2 \mathrm{mg} / \mathrm{dL}$ to $150.8 \mathrm{mg} / \mathrm{dL}$ [105].

The most important hypoglycemic active substances in pumpkin are non-pectines polysaccharides and pectines from pulp, proteins and oil obtained from seeds [107-109]. Alenazi et al. [118] reported a clinical case of a 12-year-old Asian diabetic patient that ate every day for four months $200 \mathrm{~g}$ of pumpkin. After two months of daily pumpkin consumption, a decrease of glycosylated hemoglobin $(\mathrm{HbA} 1 \mathrm{C})$ from $10.8 \%$ to $8.5 \%$ was observed [118]. The same positive hypoglycemic effect was also revealed in another study by Jain et al. [119]. Fourteen patients diagnosed with type 2 diabetes received C. ficifolia juice for 40 days, and glycosylated hemoglobin decreased with 22.5\% [119]. Shi et al. [120] investigated the antidiabetic activity of pumpkin carbohydrate granules in patients with type 2 diabetes compared to a control placebo group. After one month of treatment, both blood and urine glucose levels were significantly decreased compared with the placebo control group [120]. The results of a randomized, placebo-controlled trial conducted showed that a rich diet in pumpkin (C. maxima) seeds significantly reduced postprandial blood glucose of adults with normal glycaemia [121]. This study included 25 normoglycemic adults who consumed daily $65 \mathrm{~g}$ of pumpkin seeds [121]. Possible mechanisms of antihyperglycemic action of Cucurbita species are not fully understood but several studies investigated this subject in the last decades. Zhang et al. [122] demonstrated that C. moschata heteropolysaccharides regenerate pancreatic islets by stimulating proliferation of pancreatic $\beta$-cells. Quanhong et al. [123] showed that polysaccharides bounded by protein (polysaccharide $41.21 \%$ and protein $10.13 \%$ ) increase glucose tolerance level and reduce hyperglycemia. In the light of these results, supplements with natural extracts from Cucurbita plants can be considered as alternative hypoglycemic products and further multicenter randomized studies can confirm these results.

\subsection{Pharmacotherapeutic Effects in Low Urinary Tract Diseases}

Benign prostatic hyperplasia $(\mathrm{BPH})$ represents an increase in the volume of the prostate under the influence of androgenic hormones, and $70 \%$ of aging men suffer from this condition. Since clinical evolution of urinary signs is slow, prevention of BPH is useful, phytotherapy being an alternative way [124]. For example, oil obtained from C. pepo seeds is traditionally used to treat urinary symptoms in $\mathrm{BPH}$ as the daily frequency of urination, nycturia, time of the bladder emptying and residual volume [110,111]. The main mechanism through which these effects are obtained is represented by the inhibition of 5- $\alpha$-reductase. This enzyme is required to convert testosterone to dihydrotestosterone, which has a higher affinity than testosterone for androgen receptors. As a result, protein synthesis increases the volume of the prostate implicitly [113].

In a multicenter clinical trial, thousands of patients diagnosed with BPH were treated with capsules containing $500 \mathrm{mg}$ of $C$. pepo seeds extracts. Their quality of life has been significantly improved by reducing the urinary symptoms of $\mathrm{BPH}[125]$.

Other modern studies have shown pharmacotherapeutic synergism in BPH when C. Pepo is administrated simultaneously with other plants. Thus, the combination with Serenoa repens (W. Bartram) Small significantly improved the urinary symptoms of BPH and decreased blood dihydrotestosterone levels [111]. Hong et al. [112] obtained similar results on urinary symptoms in Korean men with BPH treated with $320 \mathrm{mg}$ of $C$. pepo plus $320 \mathrm{mg}$ of $S$. repens. They also observed a decrease in prostatic antigen levels after the treatment, but without changes in prostate volume [112]. In a randomized Phase II clinical trial carried out by Coulson et al. [126] the efficacy of the ProstateEZE Max formulation obtained from a mixture of plants traditionally used in treating BPH was evaluated. ProstateEZE is a 
natural formulation containing C. pepo, S. repens, Pygeum africanum Hook.f., E. parviflorum Schreb. and lycopene. Fifty-seven male patients diagnosed with BPH were selected in the study. Thirty-two of them received a capsule of ProstateEZE Max daily for three consecutive months, and 25 patients were treated with a placebo. In patients treated with Prostate EZE, the clinical symptoms of BPH decreased by $35.9 \%$ compared with only $8.3 \%$ for the placebo. The frequency of nocturnal urination was reduced with 39.3\% in subjects treated for three months with ProstateEZE compared to the placebo group [126].

Due to these beneficial therapeutic effects of Cucurbita plants in BPH, the European Medicines Agency approved the use of $C$. pepo for both BPH and other bladder disorders, such as urinary stress incontinence in women [127].

Urinary stress incontinence occurs when pelvic muscles that support the bladder and the sphincter muscle, which controls the urinary flow, are weakened. This disorder is associated with aging in women. The main symptom is urinary incontinence [115]. The seeds extract of $C$. pepo have a therapeutic effect in this condition through a double mechanism. Directly by relaxing the bladder muscles leading to a decrease in nycturia and indirectly through a hormonal mechanism by inhibiting 5 - $\alpha$ reductase. This inhibition determines the anabolic effects that strengthen the bladder sphincter muscles [115,127]. The main chemical compounds in the pumpkin seeds that explain these effects are sterols (sitosterol, spinasterol) and fatty oil, which contain oleic, linoleic, palmitic acids and tocopherol) [114]. Gažová et al. [128] demonstrated these effects in a study of 86 women with urinary incontinence stress who were treated for twelve weeks with the preparation of a plant mix: C. pepo, Equisetum arvense L. and Linum usitatissimum L. Episodes of urinary incontinence during the day were reduced to $35 \%$ and nocturnal urinary frequency to $54 \%$ [128].

Overactive bladder syndrome $(\mathrm{OAB})$ is characterized by the frequent urge to urinate during the day and night, followed by an involuntary loss of urine [116]. A human clinical trial conducted by Shim et al. (2014) investigated the efficacy and utility of Cucuflavone (tablets with a mixture of plant extracts $87.5 \%$ C. pepo seeds and $12.5 \%$ soy) in reducing OAB symptoms [116]. The active compounds of Cucuflavone are phenols (pyrogallol) and isoflavones (genistein, daidzin). One hundred and twenty patients were included in the study, divided into two groups: The Cucuflavone group and the placebo group. Patients from Cucuflavone group received two tablets twice a day (a total of $875 \mathrm{mg}$ of $C$. pepo seed extract and $125 \mathrm{mg}$ of soy extract daily) for twelve weeks. The final results of the investigation showed that urinary incontinence, the frequency of daily and nocturnal urination was statistically significantly reduced compared to the initial parameters [116]. In a recent investigation, Nishimura et al. obtained similar results. They confirmed the efficacy of C. maxima seeds oil on urinary disorders in OAB. Forty-five subjects with $\mathrm{OAB}$ were included and treated daily with $10 \mathrm{~g}$ of $\mathrm{C}$. maxima seed oil for twelve weeks. At the end of the investigation, the frequency of average daily urination was reduced from 10.96 to 8.00 [117].

\section{Conclusions and Future Perspectives}

In short, the use of Cucurbita species and their active constituents in various clinical and pharmacological studies revealed the presence of multiple, effective and useful compounds, which provide the opportunity for further production of antidiabetic, analgesic, anti-inflammatory and cardioprotective drugs and foods. Indeed, the use of Cucurbita plants in the treatment of several diseases, including gastrointestinal disorders, intestinal parasites and hypertension, dates from a long time ago. The antimicrobial and antioxidant properties of these species have triggered a huge interest for multiple applications. First of all, free radicals are generated through various metabolic activities in the body, ultimately resulting in various deleterious diseases [99]. These diseases can be treated by supplementation of cucurbits as activities of some cucurbits are comparable with commercially available antibiotics. The present review markedly highlights that Cucurbita species have preventive and therapeutic abilities for treatment of different diseases. The presence of active phytochemicals in Cucurbita species further strengthens the opportunity for their application as an upcoming anticancer, antidiabetic, analgesic, anti-inflammatory and cardioprotective drugs, as well as foods. Finally, and 
not the least important, the application of Cucurbitaceae members in public health, as nutraceuticals is associated with great availability and a good safety profile.

Author Contributions: All authors contributed equally to this work. J.S.-R., M.M., N.M., and R.C., critically reviewed the manuscript. All the authors read and approved the final manuscript.

Funding: This research received no external funding.

Acknowledgments: This work was supported by CONICYT PIA/APOYO CCTE AFB170007. N. Martins would like to thank the Portuguese Foundation for Science and Technology (FCT-Portugal) for the Strategic project ref. UID/BIM/04293/2013 and "NORTE2020-Northern Regional Operational Program" (NORTE-01-0145-FEDER-000012) and C.F.R. for the project UID/EQU/00511/2019-Laboratory for Process Engineering, Environment, Biotechnology, and Energy-LEPABE funded by national funds through FCT/MCTES (PIDDAC)

Conflicts of Interest: The authors declare no conflict of interest.

\section{References}

1. Marie-Magdeleine, C.; Hoste, H.; Mahieu, M.; Varo, H.; Archimede, H. In vitro effects of Cucurbita moschata seed extracts on Haemonchus contortus. Vet. Parasitol. 2009, 161, 99-105. [CrossRef] [PubMed]

2. Yang, B.M.; Yang, S.T. A preliminary study on the cultivating technique of Cucurbita pepo cv Dayangua. Spec. Econ. Amin. Plant 2000, 3, 28-34.

3. Adnan, M.; Gul, S.; Batool, S.; Fatima, B.; Rehman, A.; Yaqoob, S.; Shabir, H.; Yousaf, T.; Mussarat, S.; Ali, N.; et al. A review on the ethnobotany, phytochemistry, pharmacology and nutritional composition of Cucurbita pepo L. J. Phytopharm. 2017, 6, 133-139.

4. Andolfo, G.; Di Donato, A.; Darrudi, R.; Errico, A.; Aiese Cigliano, R.; Ercolano, M.R. Draft of Zucchini (Cucurbita pepo L.) Proteome: A Resource for Genetic and Genomic Studies. Front. Genet. 2017, 8, 181. [CrossRef] [PubMed]

5. Dubey, S.D. Overview on Cucurbita maxima. Int. J. Phytopharm. 2012, 2, 68-71. [CrossRef]

6. Paris, H.S. Historical records, origins, and development of the edible cultivar groups of Cucurbita pepo (Cucurbitaceae). Econ. Bot. 1989, 43, 423-443. [CrossRef]

7. Ratnam, N. A review on Cucurbita pepo. Int. J. Pharm. Phytochem. Res. 2017, 9, 1190-1194. [CrossRef]

8. Salehi, B.; Valussi, M.; Jugran, A.K.; Martorell, M.; Ramírez-Alarcón, K.; Stojanović-Radić, Z.Z.; Antolak, H.; Kręgiel, D.; Mileski, K.S.; Sharifi-Rad, M.; et al. Nepeta species: From farm to food applications and phytotherapy. Trends Food Sci. Technol. 2018, 80, 104-122. [CrossRef]

9. Mishra, A.P.; Sharifi-Rad, M.; Shariati, M.A.; Mabkhot, Y.N.; Al-Showiman, S.S.; Rauf, A.; Salehi, B.; Župunski, M.; Sharifi-Rad, M.; Gusain, P.; et al. Bioactive compounds and health benefits of edible Rumex species-A review. Cell. Mol. Biol. 2018, 64, 27-34. [CrossRef]

10. Fapohunda, S.; Adewumi, A.; Jegede, D. Cucurbitaceae - the family that nourishes and heals. MicroMedicine 2018, 6, 85-93.

11. Phillips, K.M.; Ruggio, D.M.; Ashraf-Khorassani, M. Phytosterol composition of nuts and seeds commonly consumed in the United States. J. Agric. Food Chem. 2005, 53, 9436-9445. [CrossRef] [PubMed]

12. Ryan, E.; Galvin, K.; O'Connor, T.P.; Maguire, A.R.; O’Brien, N.M. Phytosterol, squalene, tocopherol content and fatty acid profile of selected seeds, grains, and legumes. Plant Foods Hum. Nutr. 2007, 62, 85-91. [CrossRef] [PubMed]

13. Applequist, W.L.; Avula, B.; Schaneberg, B.T.; Wang, Y.H.; Khan, I.A. Comparative fatty acid content of seeds of four Cucurbita species grown in a common (shared) garden. J. Food Compos. Anal. 2006, 19, 606-611. [CrossRef]

14. Sabudak, T. Fatty acid composition of seed and leaf oils of pumpkin, walnut, almond, maize, sunflower and melon. Chem. Nat. Compd. 2007, 43, 465-467. [CrossRef]

15. Stevenson, D.G.; Eller, F.J.; Wang, L.; Jane, J.L.; Wang, T.; Inglett, G.E. Oil and tocopherol content and composition of pumpkin seed oil in 12 cultivars. J. Agric. Food Chem. 2007, 55, 4005-4013. [CrossRef] [PubMed]

16. Glew, R.H.; Glew, R.S.; Chuang, L.T.; Huang, Y.S.; Millson, M.; Constans, D.; Vanderjagt, D.J. Amino acid, mineral and fatty acid content of pumpkin seeds (Cucurbita spp) and Cyperus esculentus nuts in the Republic of Niger. Plant Foods Hum. Nutr. 2006, 61, 49-54. [CrossRef] 
17. Talukdar, S.N.; Hossain, M.N. Phytochemical, Phytotherapeutical and Pharmacological Study of Momordica dioica. Evid.-Based Complement. Altern. Med. 2014, 2014, 806082. [CrossRef]

18. Vijayakumar, M.; Eswaran, M.B.; Ojha, S.K.; Rao, C.V.; Rawat, A.K.S. Antiulcer activity of hydroalcohol extract of Momordica dioica roxb. Fruit. Indian J. Pharm. Sci. 2011, 73, 572-577. [CrossRef]

19. Chandrasekar, B.; Mukherjee, B.; Mukherjee, S.K. Blood sugar lowering potentiality of selected Cucurbitaceae plants of Indian origin. Indian J. Med Res. 1989, 90, 300-305. [PubMed]

20. Huseini, H.F.; Darvishzadeh, F.; Heshmat, R.; Jafariazar, Z.; Raza, M.; Larijani, B. The clinical investigation of Citrullus colocynthis (L.) schrad fruit in treatment of type II diabetic patients: A randomized, double blind, placebo-controlled clinical trial. Phytother. Res. 2009, 23, 1186-1189. [CrossRef]

21. Rashidi, A.A.; Mirhashemi, S.M.; Taghizadeh, M.; Sarkhail, P. Iranian medicinal plants for diabetes mellitus: A systematic review. Pak. J. Biol. Sci. 2013, 16, 401-411.

22. Jain, A.; Singhai, A.K. Effect of Momordica dioica Roxb on gentamicin model of acute renal failure. Nat. Prod. Res. 2010, 24, 1379-1389. [CrossRef]

23. Menendez-Baceta, G.; Aceituno-Mata, L.; Molina, M.; Reyes-García, V.; Tardío, J.; Pardo-De-Santayana, M. Medicinal plants traditionally used in the northwest of the Basque Country (Biscay and Alava), Iberian Peninsula. J. Ethnopharmacol. 2014, 152, 113-134. [CrossRef]

24. Peter, E.L.; Rumisha, S.F.; Mashoto, K.O.; Malebo, H.M. Ethno-medicinal knowledge and plants traditionally used to treat anemia in Tanzania: A cross sectional survey. J. Ethnopharmacol. 2014, 154, 767-773. [CrossRef]

25. Kujawska, M.; Pieroni, A. Plants used as food and medicine by polish migrants in Misiones, Argentina. Ecol. Food Nutr. 2015, 54, 255-279. [CrossRef]

26. Vijayakumar, S.; Morvin Yabesh, J.E.; Prabhu, S.; Manikandan, R.; Muralidharan, B. Quantitative ethnomedicinal study of plants used in the Nelliyampathy hills of Kerala, India. J. Ethnopharmacol. 2015, 161, 238-254. [CrossRef] [PubMed]

27. Mahomoodally, M.F.; Mootoosamy, A.; Wambugu, S. Traditional therapies used to manage diabetes and related complications in Mauritius: A comparative ethnoreligious study. Evid.-Based Complement. Altern. Med. 2016, 2016, 1-25. [CrossRef] [PubMed]

28. Motti, R.; Motti, P. An ethnobotanical survey of useful plants in the agro Nocerino Sarnese (Campania, southern Italy). Hum. Ecol. 2017, 45, 865-878. [CrossRef]

29. Nayak, D.; Ashe, S.; Rauta, P.R.; Nayak, B. Assessment of antioxidant, antimicrobial and anti-osteosarcoma potential of four traditionally used Indian medicinal plants. J. Appl. Biomed. 2017, 15, 119-132. [CrossRef]

30. Ramzan, S.; Soelberg, J.; Jäger, A.K.; Cantarero-Arévalo, L. Traditional medicine among people of Pakistani descent in the capital region of Copenhagen. J. Ethnopharmacol. 2017, 196, 267-280. [CrossRef] [PubMed]

31. Agyare, C.; Spiegler, V.; Asase, A.; Scholz, M.; Hempel, G.; Hensel, A. An ethnopharmacological survey of medicinal plants traditionally used for cancer treatment in the Ashanti region, Ghana. J. Ethnopharmacol. 2018, 212, 137-152. [CrossRef] [PubMed]

32. Balcha, A. Medicinal plants used in traditional medicine by Oromo people, Ghimbi District, Southwest Ethiopia. J. Ethnobiol. Ethnomed. 2014, 10, 1-15.

33. Alonso-Castro, A.J.; Dominguez, F.; Zapata-Morales, J.R.; Carranza-Alvarez, C. Plants used in the traditional medicine of Mesoamerica (Mexico and Central America) and the Caribbean for the treatment of obesity. J. Ethnopharmacol. 2015, 175, 335-345. [CrossRef] [PubMed]

34. Rigat, M.; Vallès, J.; Dambrosio, U.; Gras, A.; Iglésias, J.; Garnatje, T. Plants with topical uses in the Ripollès district (Pyrenees, Catalonia, Iberian Peninsula): Ethnobotanical survey and pharmacological validation in the literature. J. Ethnopharmacol. 2015, 164, 162-179. [CrossRef] [PubMed]

35. Asowata-Ayodele, A.M.; Afolayan, A.J.; Otunola, G.A. Ethnobotanical survey of culinary herbs and spices used in the traditional medicinal system of Nkonkobe Municipality, Eastern Cape, South Africa. South Afr. J. Bot. 2016, 104, 69-75. [CrossRef]

36. Jaradat, N.A.; Shawahna, R.; Eid, A.M.; Al-Ramahi, R.; Asma, M.K.; Zaid, A.N. Herbal remedies use by breast cancer patients in the West Bank of Palestine. J. Ethnopharmacol. 2016, 178, 1-8. [CrossRef]

37. Meragiaw, M.; Asfaw, Z.; Argaw, M. The Status of Ethnobotanical Knowledge of Medicinal Plants and the Impacts of Resettlement in Delanta, Northwestern Wello, Northern Ethiopia. Evid.-Based Complement. Altern. Med. 2016, 2016, 5060247. [CrossRef] 
38. Odoh, U.E.; Uzor, P.F.; Eze, C.L.; Akunne, T.C.; Onyegbulam, C.M.; Osadebe, P.O. Medicinal plants used by the people of Nsukka Local Government Area, south-eastern Nigeria for the treatment of malaria: An ethnobotanical survey. J. Ethnopharmacol. 2018, 218, 1-15. [CrossRef]

39. Suroowan, S.; Mahomoodally, M.F. A comparative ethnopharmacological analysis of traditional medicine used against respiratory tract diseases in Mauritius. J. Ethnopharmacol. 2016, 177, 61-80. [CrossRef]

40. Peiretti, P.G.; Meineri, G.; Gai, F.; Longato, E.; Amarowicz, R. Antioxidative activities and phenolic compounds of pumpkin (Cucurbita pepo) seeds and amaranth (Amaranthus caudatus) grain extracts. Nat. Prod. Res. 2017, 31, 2178-2182. [CrossRef] [PubMed]

41. Azevedo-Meleiro, C.H.; Rodriguez-Amaya, D.B. Qualitative and quantitative differences in carotenoid composition among Cucurbita moschata, Cucurbita maxima, and Cucurbita pepo. J. Agric. Food Chem. 2007, 55, 4027-4033. [CrossRef] [PubMed]

42. Maria, L.; Carvalho, J.D.; Barros, P.; Luiz, R.; Godoy, D.O.; Pacheco, S.; Henrique, P.; Luiz, J.; Carvalho, V.D.; Regini, M.; et al. Total carotenoid content, $\alpha$-carotene and $\beta$-carotene, of landrace pumpkins (Cucurbita moschata Duch): A preliminary study. Food Res. Int. 2012, 47, 337-340.

43. Perez Gutierrez, R.M. Review of Cucurbita pepo (Pumpkin) its Phytochemistry and Pharmacology. Med. Chem. 2016, 6, 12-21. [CrossRef]

44. Chandrika, U.G.; Basnayake, B.M.L.B.; Athukorala, I.; Colombagama, P.W.N.M.; Goonetilleke, A. Carotenoid Content and In Vitro Bioaccessibility of Lutein in Some Leafy Vegetables Popular in Sri Lanka. J. Nutr. Sci. Vitaminol. 2010, 56, 203-207. [CrossRef]

45. Mi, Y.K.; Eun, J.K.; Young-Nam, K.; Changsun, C.; Bo-Hieu, L. Comparison of the chemical compositions and nutritive values of various pumpkin (Cucurbitaceae) species and parts. Nutr. Res. Pract. 2012, 6, $21-27$. [CrossRef]

46. Yang, R.Y.; Lin, S.; Kuo, G. Content and distribution of flavonoids among 91 edible plant species. Asia Pac. J. Clin. Nutr. 2008, 17, 275-279.

47. Sreeramulu, D.; Raghunath, M. Antioxidant activity and phenolic content of roots, tubers and vegetables commonly consumed in India. Food Res. Int. 2010, 43, 1017-1020. [CrossRef]

48. Koo, M.H.; Suhaila, M. Flavonoid (Myricetin, Quercetin, Kaempferol, Luteolin and Apigenin) Content of Edible Tropical Plants. J. Agric. Food Chem. 2001, 49, 3106-3112.

49. Mongkolsilp, S.; Pongbupakit, I.; Sae-Lee, N.; Sitthihaworm, W.; Article, O. Radical Scavenging Activity and Total Phenolic Content of Medicinal Plants Used in Primary Health Care Savitree Mongkolsilp, Isara Pongbupakit, Nittaya Sae-Lee and Worapan Sitthithaworn. Swu J. Pharm. Sci. 2004, 9, 32-35.

50. Iswaldi, I.; Gómez-Caravaca, A.M.; Lozano-Sánchez, J.; Arráez-Román, D.; Segura-Carretero, A.; Fernández-Gutiérrez, A. Profiling of phenolic and other polar compounds in zucchini (Cucurbita pepo L.) by reverse-phase high-performance liquid chromatography coupled to quadrupole time-of-flight mass spectrometry. Food Res. Int. 2013, 50, 77-84. [CrossRef]

51. Andjelkovic, M.; Van Camp, J.; Trawka, A.; Verhé, R. Phenolic compounds and some quality parameters of pumpkin seed oil. Eur. J. Lipid Sci. Technol. 2010, 112, 208-217. [CrossRef]

52. Peričin, D.; Krimer, V.; Trivić, S.; Radulović, L. The distribution of phenolic acids in pumpkin's hull-less seed, skin, oil cake meal, dehulled kernel and hull. Food Chem. 2009, 113, 450-456. [CrossRef]

53. El-Kamali, H.H.; Mahjoub, S.A.T. Antibacterial activity of Francoeuria crispa, Pulicaria undulata, Ziziphus spina-christi and Cucurbita pepo against seven standard pathogenic bacteria. Ethnobot. Leafl. 2009, 13, 722-733.

54. Dubey, A.; Mishra, N.; Singh, N. Antimicrobial activity of some selected vegetables. Int. J. Appl. Biol. Pharm. Technol. 2010, 1, 994-999.

55. Sood, A.; Kaur, P.; Gupta, R. Phytochemical screening and antimicrobial assay of various seeds extract of Cucurbitaceae family. Int. J. Appl. Biol. Pharm. Technol. 2012, 3, 401-409.

56. Grzybek, M.; Kukula-Koch, W.; Strachecka, A.; Jaworska, A.; Phiri, A.M.; Paleolog, J.; Tomczuk, K. Evaluation of anthelmintic activity and composition of pumpkin (Cucurbita pepo L.) seed extracts-in vitro and in vivo studies. Int. J. Mol. Sci. 2016, 17, 1456. [CrossRef]

57. Al-Ghazal, A.T. Evaluation of Antibacterial Effect of Cucurbita pepo (Yakten) Extracts on Multi-antibiotic Resistance Bacterial Strains Isolated From Human Urinary Tract Infections. Rafidain J. Sci. 2012, 23, 1-7.

58. Chonoko, U.G.; Rufai, A.B. Phytochemical screening and antibacterial activity of Curbita pepo (Pumpkin) against Staphylococcus aureus and Salmonella typhi. J. Pure Appl. Sci. 2011, 4, 145-147. 
59. Jasim, S.; Alwan, A.N.; Altimimi, H.W.; Kareem, K.H. Evaluation of antimicrobial activity of flavonoids extract from Cucurbita pepo leaves. Bas. J. Vet. Res. 2010, 9, 10-17.

60. Noumedem, J.A.K.; Mihasan, M.; Lacmata, S.T.; Stefan, M.; Kuiate, J.R.; Kuete, V. Antibacterial activities of the methanol extracts of ten Cameroonian vegetables against Gram-negative multidrug-resistant bacteria. BMC Complement. Altern. Med. 2013, 13, 26. [CrossRef]

61. Dar, A.H.; Sofi, S.A. Pumpkin the functional and therapeutic ingredient: A review. Int. J. Food Sci. Nutr. 2017, 2, 165-170.

62. Abed El-Aziz, A.; Abed El-Aziz, H. Antimicrobial proteins and oil seeds from pumpkin. Nat. Sci. 2011, 9, 105-119.

63. Elhadi, I.M.; Koko, S.W.; Dahab, M.M.; El Imam, J.M.; El Mageed, M.A.E. Antigiardial activity of some Cucurbita species and Lagenaria siceraria. J. For. Prod. Ind. 2013, 2, 43-47.

64. Muruganantham, N.; Solomon, S.; Senthamilselvi, M.M. Anti-cancer activity of Cucumis sativus (cucumber) flowers against human liver cancer. Int. J. Pharm. Clin. Res. 2016, 8, 39-41.

65. Geetha, S. Antimicrobial activity of selected vegetable peels against water borne pathogens. Int. J. Adv. Pharm. Biol. Chem. 2014, 3, 937-940.

66. Kabbashi, A.S.; Koko, W.S.; Mohammed, S.E.A.; Musa, N.; Elbadri, E.; Dahab, M.M.; Mohammed, A.K. In vitro a moebicidal, antimicrobial and antioxidant activities of the plants Adansonia digitata and Cucurbit maxima. Adv. Med. Plant Res. 2014, 2, 50-57.

67. Ravishankar, K.; Kiranmayi, G.V.N.; Appa Reddy, G.V.; Sowjanya, V.V.L.; Baba Sainadh, V.; Lakshmi, V.G.; Prasad, T. Preliminary phytochemical screening and In-vitro antibacterial activity of Cucurbita maxima seed extract. Int. J. Res. Pharm. Chem. 2012, 2, 86-91.

68. Cassel, C.K. Policy challenges and clinical practices. Hosp. Pract. 1993, 28, 9-10. [CrossRef]

69. Wang, H.X.; $\mathrm{Ng}$, T.B. Isolation of cucurmoschin, a novel antifungal peptide abundant in arginine, glutamate and glycine residues from black pumpkin seeds. Peptides 2003, 24, 969-972. [CrossRef]

70. Barbieri, L.; Polito, L.; Bolognesi, A.; Ciani, M.; Pelosi, E.; Farini, V.; Stirpe, F. Ribosome-inactivating proteins in edible plants and purification and characterization of a new ribosome-inactivating protein from Cucurbita moschata. Biochim. Biophys. Acta 2006, 760,783-792. [CrossRef]

71. Cheong, N.E.; Choi, Y.O.; Kim, W.Y.; Bae, I.S.; Cho, M.J.; Hwang, I.; Lee, S.Y. Purification and characterization of an antifungal PR-5 protein from pumpkin leaves. Mol. Cells 1997, 7, 214-219.

72. Park, S.C.; Lee, J.R.; Kim, J.Y.; Hwang, I.; Nah, J.W.; Cheong, H.; Hahm, K.S. Pr-1, a novel antifungal protein from pumpkin rinds. Biotechnol. Lett. 2009, 32, 125-130. [CrossRef] [PubMed]

73. Karanja, J.; Mugendi, J.; Muchugi, A.; Karanja, J.K.; Mugendi, B.J.; Khamis, F.M.; Muchugi, A.N. Nutritional evaluation of some kenyan pumpkins (Cucurbita spp.). Int. J. Agric. For. 2016, 4, 195-200.

74. Bardaa, S.; Ben Halima, N.; Aloui, F.; Ben Mansour, R.; Jabeur, H.; Bouaziz, M.; Sahnoun, Z. Oil from pumpkin (Cucurbita pepo L.) seeds: Evaluation of its functional properties on wound healing in rats. Lipids Health Dis. 2016, 15, 783-792. [CrossRef]

75. Seo, J.S.; Burri, B.J.; Quan, Z.; Neidlinger, T.R. Extraction and chromatography of carotenoids from pumpkin. J. Chromatogr. A 2005, 1073, 371-375. [CrossRef] [PubMed]

76. van Vugt, R.M.; Rijken, P.J.; Rietveld, A.G.; van Vugt, A.C.; Dijkmans, B.A.C. Antioxidant intervention in rheumatoid arthritis: Results of an open pilot study. Clin. Rheumatol. 2008, 27, 771-775. [CrossRef]

77. Dixon, W.G. Rheumatoid arthritis: Biological drugs and risk of infection. Lancet 2015, 386, 224-225. [CrossRef]

78. Fokou, E.A.M. Preliminary nutritional evaluation of five species of egusi seeds in Cameroon. Afr. J. Food Agric. Nutr. Dev. 2004, 4, 1-11. [CrossRef]

79. Duncan, K.L.K.; Duncan, M.D.; Alley, M.C.; Sausville, E.A. Cucurbitacin E-induced disruption of the actin and vimentin cytoskeleton in prostate carcinoma cells. Biochem. Pharmacol. 1996, 52, 1553-1560. [CrossRef]

80. Fang, X.; Phoebe, C.H.; Pezzuto, J.M.; Fong, H.H.; Farnsworth, N.R.; Yellin, B.; Hecht, S.M. Plant anticancer agents, XXXIV. Cucurbitacins from Elaeocarpus dolichostylus. J. Nat. Prod. 1984, 47, 988-993. [CrossRef] [PubMed]

81. Jayaprakasam, B.; Seeram, N.P.; Nair, M.G. Anticancer and antiinflammatory activities of cucurbitacins from Cucurbita andreana. Cancer Lett. 2003, 189, 11-16. [CrossRef]

82. Chan, K.T.; Meng, F.Y.; Li, Q.; Ho, C.Y.; Lam, T.S.; To, Y.; Toh, M. Cucurbitacin B induces apoptosis and S phase cell cycle arrest in BEL-7402 human hepatocellular carcinoma cells and is effective via oral administration. Cancer Lett. 2010, 294, 118-124. [CrossRef] [PubMed] 
83. Liu, T.; Zhang, M.; Zhang, H.; Sun, C.; Deng, Y. Inhibitory effects of cucurbitacin B on laryngeal squamous cell carcinoma. Eur. Arch. Oto-Rhino-Laryngol. 2008, 265, 1225-1232. [CrossRef]

84. Wakimoto, N.; Yin, D.; O'Kelly, J.; Haritunians, T.; Karlan, B.; Said, J.; Koeffler, H.P. Cucurbitacin B has a potent antiproliferative effect on breast cancer cells in vitro and in vivo. Cancer Sci. 2008, 99, 1793-1797. [CrossRef]

85. Zhang, M.; Zhang, H.; Sun, C.; Shan, X.; Yang, X.; Li-Ling, J.; Deng, Y. Targeted constitutive activation of signal transducer and activator of transcription 3 in human hepatocellular carcinoma cells by cucurbitacin $B$. Cancer Chemother. Pharmacol. 2009, 63, 635-642. [CrossRef] [PubMed]

86. Chan, K.T.; Li, K.; Liu, S.L.; Chu, K.H.; Toh, M.; Xie, W.D. Cucurbitacin B inhibits STAT3 and the Raf/MEK/ERK pathway in leukemia cell line K562. Cancer Lett. 2010, 289, 46-52. [CrossRef] [PubMed]

87. Carvalho, L.J.; Smiderle, L.A.S.; Carvalho, J.L.V.; Cardoso, F.S.N.; Koblitz, M.G.B. Assessment of carotenoids in pumpkins after different home cooking conditions. Food Sci. Technol. 2014, 34, 365-370. [CrossRef]

88. Konoshima, T.; Takasaki, M.; Kozuka, M.; Nagao, T.; Okabe, H.; Irino, N.; Nishino, H. Inhibitory effects of cucurbitane triterpenoids on Epstein-Barr virus activation and two-stage carcinogenesis of skin tumor. Biol. Pharm. Bull. 1994, 18, 284-287. [CrossRef]

89. Shokrzadeh, M.; Azadbakht, M.; Ahangar, N.; Hashemi, A.; Saravi, S. Cytotoxicity of hydro-alcoholic extracts of Cucurbita pepo and Solanum nigrum on HepG2 and CT26 cancer cell lines. Pharmacogn. Mag. 2010, 6, 176. [CrossRef]

90. Wang, D.C.; Xiang, H.; Li, D.; Gao, H.; Cai, H.; Wu, L.J.; Deng, X.M. Purine-containing cucurbitane triterpenoids from Cucurbita pepo cv dayangua. Phytochemistry 2008, 69, 1434-1438. [CrossRef]

91. Ren, S.; Ouyang, D.Y.; Saltis, M.; Xu, L.H.; Zha, Q.B.; Cai, J.Y.; He, X.H. Anti-proliferative effect of 23,24-dihydrocucurbitacin F on human prostate cancer cells through induction of actin aggregation and cofilin-actin rod formation. Cancer Chemother. Pharmacol. 2012, 70, 415-424. [CrossRef]

92. Dakeng, S.; Duangmano, S.; Jiratchariyakul, W.; U-Pratya, Y.; Bögler, O.; Patmasiriwat, P. Inhibition of Wnt signaling by cucurbitacin B in breast cancer cells: Reduction of Wnt-associated proteins and reduced translocation of galectin-3-mediated $\beta$-catenin to the nucleus. J. Cell. Biochem. 2012, 113, 49-60. [CrossRef]

93. Attard, E.; Cuschieri, A.; Scicluna-Spiteri, A.; Brincat, M.P. The effects of cucurbitacin E on two lymphocyte models. Pharm. Biol. 2004, 42, 170-175. [CrossRef]

94. Alam, U.; Asghar, O.; Azmi, S.; Malik, R.A. General aspects of diabetes mellitus. Handb. Clin. Neurol. 2014, 126, 211-222. [PubMed]

95. Sharifi-Rad, M.; Fokou, P.V.T.; Sharopov, F.; Martorell, M.; Ademiluyi, A.O.; Rajkovic, J.; Salehi, B.; Martins, N.; Iriti, M.; Sharifi-Rad, J. Antiulcer agents: From plant extracts to phytochemicals in healing promotion. Molecules 2018, 23, 1751. [CrossRef] [PubMed]

96. Mishra, A.P.; Saklani, S.; Salehi, B.; Parcha, V.; Sharifi-Rad, M.; Milella, L.; Iriti, M.; Sharifi-Rad, J.; Srivastava, M. Satyrium nepalense, a high altitude medicinal orchid of Indian Himalayan region: Chemical profile and biological activities of tuber extracts. Cell. Mol. Biol. 2018, 64, 35-43. [CrossRef]

97. Sharifi-Rad, M.; Nazaruk, J.; Polito, L.; Morais-Braga, M.F.B.; Rocha, J.E.; Coutinho, H.D.M.; Salehi, B.; Tabanelli, G.; Montanari, C.; del Mar Contreras, M.; et al. Matricaria genus as a source of antimicrobial agents: From farm to pharmacy and food applications. Microbiol. Res. 2018, 215, 76-88. [CrossRef]

98. Sharifi-Rad, J.; Tayeboon, G.S.; Niknam, F.; Sharifi-Rad, M.; Mohajeri, M.; Salehi, B.; Iriti, M.; Sharifi-Rad, M. Veronica persica Poir. extract - antibacterial, antifungal and scolicidal activities, and inhibitory potential on acetylcholinesterase, tyrosinase, lipoxygenase and xanthine oxidase. Cell. Mol. Biol. 2018, 64, 50-56. [CrossRef] [PubMed]

99. Sharifi-Rad, M.; Ozcelik, B.; Altın, G.; Daşkaya-Dikmen, C.; Martorell, M.; Ramírez-Alarcón, K.; Alarcón-Zapata, P.; Morais-Braga, M.F.B.; Carneiro, J.N.P.; Alves Borges Leal, A.L.; et al. Salvia spp. plants-from farm to food applications and phytopharmacotherapy. Trends Food Sci. Technol. 2018, 80, $242-263$. [CrossRef]

100. Salehi, B.; Sharopov, F.; Martorell, M.; Rajkovic, J.; Ademiluyi, A.O.; Sharifi-Rad, M.; Fokou, P.V.T.; Martins, N.; Iriti, M.; Sharifi-Rad, J. Phytochemicals in Helicobacter pylori infections: What are we doing now? Int. J. Mol. Sci. 2018, 19. [CrossRef] [PubMed]

101. Caili, F.; Huan, S.; Quanhong, L. A review on pharmacological activities and utilization technologies of pumpkin. Plant Foods Hum. Nutr. 2006, 61, 73-80. [CrossRef] [PubMed] 
102. Andrade-Cetto, A.; Heinrich, M. Mexican plants with hypoglycaemic effect used in the treatment of diabetes. J. Ethnopharmacol. 2005, 99, 325-348. [CrossRef]

103. Jia, W.; Gao, W.; Tang, L. Antidiabetic herbal drugs officially approved in China. Phytother. Res. 2003, 17, 1127-1134. [CrossRef] [PubMed]

104. Mukherjee, P.K.; Maiti, K.; Mukherjee, K.; Houghton, P.J. Leads from Indian medicinal plants with hypoglycemic potentials. J. Ethnopharmacol. 2006, 106, 1-28. [CrossRef]

105. Acosta-Patiño, J.L.; Jiménez-Balderas, E.; Juárez-Oropeza, M.A.; Díaz-Zagoya, J.C. Hypoglycemic action of Cucurbita ficifolia on Type 2 diabetic patients with moderately high blood glucose levels. J. Ethnopharmacol. 2001, 77, 99-101. [CrossRef]

106. Mahmoodpoor, A.; Medghalchi, M.; Nazemiyeh, H.; Asgharian, P.; Shadvar, K.; Hamishehkar, H. Effect of Cucurbita maxima on control of blood glucose in diabetic critically ill patients. Adv. Pharm. Bull. 2018, 8, 347-351. [CrossRef]

107. Adams, G.G.; Imran, S.; Wang, S.; Mohammad, A.; Kok, S.; Gray, D.A.; Harding, S.E. The hypoglycaemic effect of pumpkins as anti-diabetic and functional medicines. Food Res. Int. 2011, 44, 862-867. [CrossRef]

108. Cai, T.; Li, Q.; Yan, H.; Li, N. Study on the hypoglycemic action of pumpkin seed protein. J. Chin. Inst. Food Sci. Technol. 2003, 3, 7-11.

109. Xiong, X.; Cao, J. Study of extraction and isolation of effective pumpkin polysaccharide component and its reducing glycemia function. Chin. J. Mod. Appl. Pharm. 2001, 18, 662-664.

110. Gossell-Williams, M.; Davis, A.; O'Connor, N. Inhibition of testosterone-induced hyperplasia of the prostate of sprague-dawley rats by pumpkin seed oil. J. Med. Food 2006, 9, 284-286. [CrossRef]

111. PDR for Herbal Medicines, 4th ed.; Thomson Healthcare: Montvale, NJ, USA, 2007.

112. Hong, H.; Kim, C.S.; Maeng, S. Effects of pumpkin seed oil and saw palmetto oil in Korean men with symptomatic benign prostatic hyperplasia. Nutr. Res. Pract. 2009, 3, 323. [CrossRef] [PubMed]

113. Ramak, P.; Mahboubi, M. The beneficial effects of pumpkin (Cucurbita pepo L.) seed oil for health condition of men. Food Rev. Int. 2018, 1-11. [CrossRef]

114. Rezig, L.; Chouaibi, M.; Msaada, K.; Hamdi, S. Chemical composition and profile characterisation of pumpkin (Cucurbita maxima) seed oil. Ind. Crop. Prod. 2012, 37, 82-87. [CrossRef]

115. Sogabe, H.; Terado, T. Open clinical study of effects of pumpkin seed extract/soybean germ extract vixture-containing processed food on nocturia. Jpn. J. Med. Pharm. Sci. 2001, 46, 727-737.

116. Shim, B.; Jeong, H.; Lee, S.; Hwang, S.; Moon, B.; Storni, C. A randomized double-blind placebo-controlled clinical trial of a product containing pumpkin seed extract and soy germ extract to improve overactive bladder-related voiding dysfunction and quality of life. J. Funct. Foods 2014, 8, 111-117. [CrossRef]

117. Nishimura, M.; Ohkawara, T.; Sato, H.; Takeda, H.; Nishihira, J. Pumpkin seed oil extracted from Cucurbita maxima improves urinary disorder in human overactive bladder. J. Tradit. Complement. Med. 2014, 4, 72-74. [CrossRef] [PubMed]

118. Alenazi, B.; Deeb, A.; Alrowaili, A.; Alkhaldi, A.; Alanazi, A. Does pumpkin affect glycemic control in diabetic patient. Case report and literature review. Eur. J. Pharm. Med. Res. 2017, 4, 42-45.

119. Jain, A.; Mishra, M.; Yadav, D.; Khatarker, D.; Jadaun, P.; Tiwari, A.; Prasad, G. Evaluation of the antihyperglycemic, antilipidemic and antioxidant potential of Cucurbita ficifolia in human type 2 diabetes. Prog. Nutr. 2018, 20, 191-198.

120. Shi, Y.; Xiong, X.; Cao, J.; Kang, M. Effect of pumpkin polysaccharide granules on glycemic control in type 2 diabetes. Cent. South Pharm. 2003, 1, 275-276.

121. Cândido, F.G.; de Oliveira, F.C.E.; Lima, M.F.C.; Pinto, C.A.; da Silva, L.L.; Martino, H.S.D.; Alfenas, R.C.G. Addition of pooled pumpkin seed to mixed meals reduced postprandial glycemia: A randomized placebo-controlled clinical trial. Nutr. Res. 2018, 56, 90-97. [CrossRef]

122. Zhang, Y.; Chen, P.; Zhang, Y.; Jin, H.; Zhu, L.; Li, J.; Yao, H. Effects of polysaccharide from pumpkin on biochemical indicator and pancreatic tissue of the diabetic rabbits. Int. J. Biol. Macromol. 2013, 62, 574-581. [CrossRef]

123. Li, Q.; Fu, C.; Rui, Y.; Hu, G.; Cai, T. Effects of protein-bound polysaccharide isolated from pumpkin on insulin in diabetic rats. Plant Foods Hum. Nutr. 2005, 60, 13-16.

124. Allkanjari, O.; Vitalone, A. What do we know about phytotherapy of benign prostatic hyperplasia? Life Sci. 2015, 126, 42-56. [CrossRef] [PubMed] 
125. Schiebel-Schlosser, G.; Friederich, M. Phytotherapy of BPH with pumpkin seeds-a multicenter clinical trial. Phytotherapy 1998, 19, 71-76.

126. Coulson, S.; Rao, A.; Beck, S.L.; Steels, E.; Gramotnev, H.; Vitetta, L. A phase II randomised double-blind placebo-controlled clinical trial investigating the efficacy and safety of ProstateEZE Max: A herbal medicine preparation for the management of symptoms of benign prostatic hypertrophy. Complementary Ther. Med. 2013, 21, 172-179. [CrossRef]

127. Assessment Report on Cucurbita pepo L. Semen; European Medicines Agency: Amsterdam, The Netherlands, 2013.

128. Gažová, A.; Valášková, S.; Žufková, V.; Castejon, A.M.; Kyselovič, J. Clinical study of effectiveness and safety of CELcomplex@containing Cucurbita pepo seed extract and flax and casuarina on stress urinary incontinence in women. J. Tradit. Complement. Med. 2018, 9, 138-142. [CrossRef]

(C) 2019 by the authors. Licensee MDPI, Basel, Switzerland. This article is an open access article distributed under the terms and conditions of the Creative Commons Attribution (CC BY) license (http://creativecommons.org/licenses/by/4.0/). 